\title{
Large cell neuroendocrine carcinoma (LCNEC) of the ovary: A case report and review of the literature
}

\author{
Allyson Jang ${ }^{1}$, Jordan M. Newell ${ }^{2}$, Rebecca Phaeton ${ }^{3}$ and Joshua P. Kesterson ${ }^{3 *}$ \\ ${ }^{1}$ Penn State College of Medicine, Hershey, USA \\ ${ }^{2}$ Department of Pathology, Penn State Hershey Medical Center, Hershey, USA \\ ${ }^{3}$ Division of Gynecologic Oncology, Penn State Hershey Medical Center, Hershey, USA
}

\section{Introduction}

Neuroendocrine tumors consist of a spectrum of malignancies that arise from the neuroendocrine cell system. This group of tumors can be divided into well-differentiated (i.e. carcinoid) and poorly differentiated neuroendocrine neoplasms (i.e. small cell and large cell) [1]. Neuroendocrine carcinomas of the female genital tract are uncommon. More specifically, large cell neuroendocrine carcinoma (LCNEC) of the ovary is an exceedingly rare diagnosis. These malignant tumors are associated with an aggressive clinical course with a short survival, even when diagnosed at an early stage. The majority of LCNECs of the ovary are associated with surface epithelial ovarian tumors. We have identified 37 documented cases in the literature. Eight cases of primary LCNEC of the ovary have been described without any concomitant epithelial ovarian component $[1,2]$. In this report, we present a case of a primary LCNEC of the ovary without an epithelial component with a relatively prolonged survival. Additionally, we summarize the current literature regarding the management of this rare tumor.

\section{Materials and methods}

For this original and updated review, we performed a keyword search within PubMed, Ovid, and Cochrane Library for "large cell neuroendocrine tumor" and "ovary". This case report was exempt from approval by the institutional review board.

\section{Case report}

A 62 year old woman presented with a two-week history of nausea, emesis, diarrhea, and malaise. On physical exam a pelvic mass was palpated. Laboratory evaluation revealed an elevated white blood cell count $(24.28 \mathrm{~K} / \mathrm{uL})$ and CA-125 (176.8 units/mL). A CT scan demonstrated a $12 \mathrm{~cm}$ complex pelvic mass. A pelvic abscess versus neoplasm was suspected. Her leukocytosis resolved with antibiotics, but the mass persisted. She underwent an exploratory laparotomy. She was noted to have a mass adherent to the rectosigmoid colon and the left adnexa. Intraoperative pathologic examination was consistent with a poorly differentiated carcinoma. A hysterectomy, bilateral salpingooophorectomy, including resection of pelvic mass, lymphadenectomy and omentectomy was performed. The patient recovered appropriately postoperatively.

Gross pathologic inspection of her surgical specimen demonstrated a $7 \mathrm{~cm}$ left ovary with a smooth, pink serosal surface. Final histopathologic examination was consistent with a large cell neuroendocrine carcinoma (Figures 1 and 2). Metastases to the uterine serosa, colonic serosa, and right fallopian tube were identified, and as such her disease extent was consistent with FIGO stage IIB.

She was subsequently treated with a combination of intravenous cisplatin and etoposide for 6 cycles. A PET CT following the completion of therapy showed no evidence of disease. Subsequently, approximately 9 months following her initial surgery, a suspicious hypermetabolic

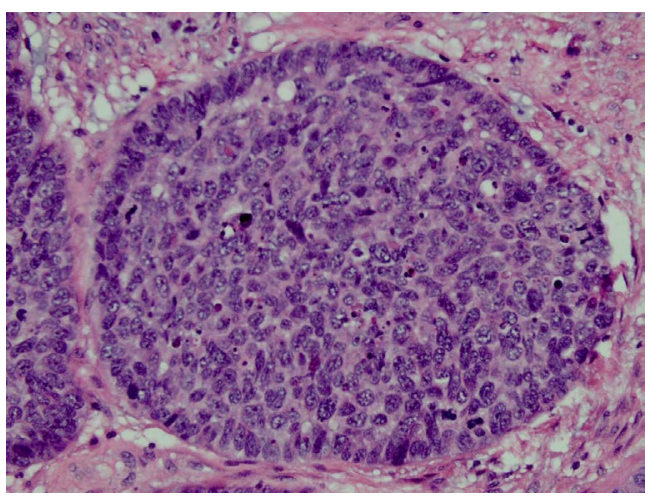

Figure 1. Hematoxylin and Eosin 40x. The large cell neuroendocrine carcinoma tumor cells are seen with a moderate amount of cytoplasm, increased mitotic activity, and some with prominent central nucleoli. The tumor cells were largely arranged in a nested growth pattern of which some nests had central necrosis (not pictured).

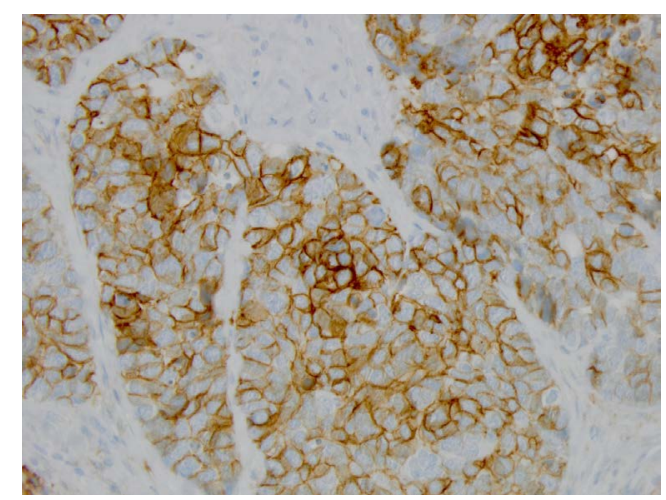

Figure 2. IHC 40x. The tumor cells were positive by immunohistochemistry for CD56 which is supportive of their neuroendocrine nature.

Correspondence to: Joshua P. Kesterson, Division of Gynecologic Oncology, Penn State Hershey Medical Center Hershey, 500 University Drive, Hershey, PA 17036, USA, Tel: (717) 531-8144, Fax: (717) 531-0007, E-mail: jkesterson@hmc.psu.edu

Received: December 10, 2016; Accepted: December 26, 2016; Published: December 28, 2016 
Table 1. Clinicopathologic, treatment modality, and follow up of patients with pure LCNEC.

\begin{tabular}{|c|c|c|c|c|c|c|c|}
\hline Reference & Age & $\begin{array}{l}\text { Presenting } \\
\text { complaint }\end{array}$ & Stage & Surgical management & Adjuvant treatment & CA-125 & Clinical Course/ follow up \\
\hline [2] & 50 & pelvic mass & IV & $\begin{array}{l}\text { TAH, BSO, partial omentectomy, } \\
\text { appendectomy (no LND) }\end{array}$ & $\begin{array}{l}\text { Paclitaxel + carboplatin } \\
\text { (progression of disease after } \\
3 \text { cycles) }\end{array}$ & 685.8 & died 3 month post operatively \\
\hline [12] & 40 & $\begin{array}{l}\text { abdominal } \\
\text { distention, fever, } \\
\text { itching }\end{array}$ & IIIc & $\begin{array}{l}\text { BSO, paraaortic lymph node } \\
\text { dissection, total omentectomy, } \\
\text { excision of sigmoid colon deposits }\end{array}$ & Etopiside + cisplatin- 5 cycles & 280.8 & $\begin{array}{l}\text { No evidence of disease- } 6 \\
\text { months }\end{array}$ \\
\hline [9] & 66 & pelvic mass & IV & $\begin{array}{l}\text { Hysterectomy, BSO, omentectomy, } \\
\text { peritoneal biopsy }\end{array}$ & $\begin{array}{l}\text { Neoadjuvant paclitaxel }+ \\
\text { carboplatin- } 4 \text { cycles; whole } \\
\text { brain radiation for brain } \\
\text { metastasis } 17 \text { months after } \\
\text { diagnosis }\end{array}$ & 6595 & $\begin{array}{l}\text { No evidence of disease- } 64 \\
\text { months after diagnosis }\end{array}$ \\
\hline [3] & 76 & abdominal pain & $\mathrm{IIb}$ & $\begin{array}{l}\text { TAH, BSO, pelvic and para- } \\
\text { aortic LND, omenetectomy, and } \\
\text { appenectomy. }\end{array}$ & None & $\begin{array}{l}\text { within normal } \\
\text { limits }\end{array}$ & $\begin{array}{l}\text { died soon after (before } \\
\text { could initatecisplatinum } \\
\text { chemotherapy) }\end{array}$ \\
\hline [4] & 46 & abdominal distention & IIIc & TAH, BSO, omentectomy & $\begin{array}{l}\text { Paclitaxel + carboplatin- } 2 \\
\text { cycles }\end{array}$ & 914 & $\begin{array}{l}\text { died } 4 \text { months post } \\
\text { operatively }\end{array}$ \\
\hline$[10]$ & 73 & dysarthria & IV & $\begin{array}{l}\text { TAH, BSO, left nephrectomy, } \\
\text { omentectomy, resection of } \\
\text { mesometrial metastasis, (CNS } \\
\text { recurrence } 2 \text { mos s/p chemo) }\end{array}$ & Paclitaxel + carboplatin & 94 & $\begin{array}{l}\text { No evidence of disease- } 1 \\
\text { year after diagnosis }\end{array}$ \\
\hline [13] & 64 & $\begin{array}{l}\text { abdominal } \\
\text { discomfort, nausea }\end{array}$ & Ia & TAH, BSO, omentectomy & $\begin{array}{l}\text { bleomycin, cisplatin, etopiside- } \\
\text { bleomycin stopped } 2 / 2 \text { pulm } \\
\text { fibrosis }\end{array}$ & 380 & $\begin{array}{l}\text { No evidence of recurrence- } 9 \\
\text { months after treatment }\end{array}$ \\
\hline$[11]$ & 27 & pelvic mass & Ia & $\begin{array}{l}\text { exploratory laparotomy, resection } \\
\text { of left ovarian mass, biopsy of right } \\
\text { ovary, infacolicomentectomy,para- } \\
\text { aortic LND, appenedectomy, pelvic } \\
\text { side wall biopsy }\end{array}$ & $\begin{array}{l}\text { Taxol + carboplatinum- } 6 \\
\text { cycles }\end{array}$ & None & $\begin{array}{l}\text { No evidence of disease- } 10 \\
\text { months after treatment }\end{array}$ \\
\hline
\end{tabular}

pelvic lymph node was detected on PET CT. She underwent a roboticassisted laparoscopic resection of this lymph node. There was no evidence of recurrence on histologic examination of this resected tissue.

However, approximately 10 months later, she was found to have a pelvic mass suspicious for recurrence. The mass measured $9 \times 7 \mathrm{~cm}$, encompassed and narrowed the sigmoid colon and was intimately involved with the common and external iliac vessels. A combination of carboplatin and etoposide chemotherapy was administered with the hopes of improving the resectability of the tumor. Following therapy, the mass did decrease in size to $7 \times 5 \mathrm{~cm}$. The patient then underwent a radical en bloc tumor resection, including vaginectomy, left colectomy, left nephrectomy, right distal ureterectomy and reimplantation, and resection of para-aortic lymph nodes. At the completion of this surgery, there was no grossly visible residual disease. She recovered well postoperatively. Pathologic examination was again consistent with recurrent large cell neuroendocrine tumor. She was treated with additional cycles of carboplatin plus etoposide. A post-treatment follow-up CT showed no evidence of recurrent or metastatic disease.

\section{Discussion}

Large cell neuroendocrine carcinomas of the ovary are extremely rare with a historically poor survival [2-5]. The precise histiogenesis of LCNEC of the ovary remains unknown. A number of theories have been proposed. As neuroendocrine cells are present in normal epithelium of the female genital tract, these may serve as the origin of neuroendocrine tumors of the ovary. Primitive endodermal cells have the ability to differentiate into endocrine and other cell types. Also, ovarian neuroendocrine tumors may arise from non-neuroendocrine cells, in which activated genes promote neuroendocrine differentiation $[5,7]$.

Secondary to its rarity, there is no standard treatment for LCNEC. Previous studies have reported chemotherapy platinum-based regimens combined with agents such as paclitaxel, etoposide, and bleomycin. Some reports have proposed that in mixed LCENC with epithelial components, optimal first line treatment should be targeted against the epithelial component [8]. For pure LCNEC, platinum agents have been used in combination with etoposide or paclitaxel (Table 1). Although most reported patients were treated with paclitaxel and carboplatin, they showed a wide range of responses from death within 3-4 months of surgery to remaining disease free for up to 10 months [2,4,9-11]. The two patients treated with etoposide and platinum therapy showed no evidence of disease after 9 months and 1 year $[12,13]$. The relatively prolonged disease free interval lends support to the combination of platinum and etoposide in the management of pure LCNEC.

Herein we have presented a case of woman with Stage IIB LCNEC tumor of the ovary treated with a surgical resections and combination chemotherapy of a platinum agent with etoposide associated with a relatively long survival. This case supports a potential role for secondary surgical cytoreduction which should be considered in appropriately selected patients. Ki et al reported the only other case of secondary cytoreduction; this in a 58-year-old woman with a recurrence in a para-aortic lymph node after initially being diagnosed with stage IA disease treated with cisplatin and paclitaxel. Unfortunately, she died of multiorgan failure 17 months after initial diagnosis [5].

In summary, LCNEC of the ovary is a rare entity. These cases have historically had an aggressive clinical course, despite surgical resection and adjuvant chemotherapy. We have presented a case of a woman with pure LCNEC responding to surgical resections and platinum plus etoposide combination chemotherapy, for a relatively prolonged overall survival (33 months). While there is no standard of care regarding this rare entity, this approach should be considered in appropriately selected patients. Secondary to their rarity, an international tumor registry for ovarian LCNEC and other rare histologic subtypes would be helpful. With the knowledge gained therein, treatment approaches could be optimized. 


\section{Acknowledgements}

The authors would like to thank Kathy Shrawder and Ann Gelder for their expertise in the preparation and formatting of this article.

\section{References}

1. Gardner GJ, Reidy-Lagunes D, Gehrig PA (2011) Neuroendocrine tumors of the gynecologic tract: A Society of Gynecologic Oncology (SGO) clinical document. Gynecol Oncol 122: 190-198. [Crossref]

2. Lin CH, Lin YC, Yu MH, Su HY (2014) Primary pure large cell neuroendocrine carcinoma of the ovary. Taiwan J Obstet Gynecol 53: 413-416. [Crossref]

3. Aslam MF, Choi C, Khulpateea N (2009) Neuroendocrine tumour of the ovary. J Obstet Gynaecol 29: 449-451. [Crossref]

4. Tsuji T, Togami S, Shintomo N, Fukamachi N, Douchi T, et al. (2008) Ovarian large cell neuroendocrine carcinoma. J Obstet Gynaecol Res 34: 726-730. [Crossref]

5. Ki E, Park J, Lee K, Bae S, Hur S (2014) Large cell neuroendocrine carcinoma of the ovary: a case report and a brief review of the literature. World J Surg Oncol 12: 314 [Crossref]

6. Veras E, Deavers MT, Silva EG, Malpica A (2007) Ovarian nonsmall cell neuroendocrine carcinoma: a clinicopathologic and immunohistochemical study of 11 cases. Am J Surg Pathol 31: 774-782. [Crossref]

7. Choi YD, Lee JS, Choi C, Park CS, Nam JH (2007) Ovarian neuroendocrine carcinoma, non-small cell type, associated with serous carcinoma. Gynecol Oncol 104: 747-752. [Crossref]

8. Voutsadakis IA (2014) Large cell neuroendocrine carcinoma of the ovary: A pathologic entity in search of clinical identity. World J Clin Oncol 5: 36-38. [Crossref]

9. Oshita T, Yamazaki T, Akimoto Y, Tanimoto H, Nagai N, et al. (2011) Clinical features of ovarian large-cell neuroendocrine carcinoma: Four case reports and review of the literature. Exp Ther Med 2: 1083-1090. [Crossref]

10. Dundr P, Fischerová D, Povýsil C, Cibula D (2008) Primary pure large-cell neuroendocrine carcinoma of the ovary. Pathol Res Pract 204: 133-137. [Crossref]

11. Behnam K, Kabus D, Behnam M (2004) Primary ovarian undifferentiated non-small cell carcinoma, neuroendocrine type. Gynecol Oncol 92: 372-375. [Crossref]

12. Shakuntala PN, Uma Devi K, Shobha K, Bafna UD, Geetashree M (2012) Pure large cell neuroendocrine carcinoma of ovary: a rare clinical entity and review of literature. Case Rep Oncol Med: 120727. [Crossref]

13. Lindboe CF (2007) Large cell neuroendocrine carcinoma of the ovary. APMIS 115: 169-176. [Crossref]

Copyright: (C2016 Jang A. This is an open-access article distributed under the terms of the Creative Commons Attribution License, which permits unrestricted use, distribution, and reproduction in any medium, provided the original author and source are credited. 